\title{
HOMOGENITAS KARAKTER DAN TRADISI KEAGAMAAN MASYARAKAT PEDESAAN DI KOTA GILEGON
}

\author{
Ahmad Suja'i \\ Sekolah Tinggi Agama Islam (STAI) Binamadani Tangerang \\ Jl. KH. Hasyim Azhari Kav. DPR Nerogtok No.236. Pinang - Tangerang \\ Email: sujaicilegon@gmail.com
}

\begin{tabular}{|l|l|l|}
\hline Diterima: 25 Februari 2017 & Revisi: 20 April 2017 & Disetujui: 20 Mei 2017 \\
\hline
\end{tabular}

\begin{abstract}
Madrasah as the oldest Islamic educational institution after boarding school has been recognized to have a very big contribution to the religious behavior of Islamic society in Indonesia. Madrasah Al-Jauharotunnaqiyyah Cibeber is one of the madrassas that has been established since 1924, which contributed in the birth of alumni-alumni who are competent in the field of religion scattered in the region of Banten and surrounding areas. In this study the authors find out, whether there is the role of alumni madrasah Al-Jauharotunnaqiyyah cibeber in shaping the character homogeneity of religious and cultural rural communities in the district area cebeber cilegon city. Based on the results of research that has been done in rural communities Cibeber District Cilegon City which consists of 6 villages, namely: Cibeber Village, Kedaleman, Karangasem, Kalitimbang, Bulakan and Cikerai Village, it can be concluded that alumni madrasah Al-Jauharotunnaqiyyah Cibeber very instrumental in forming homogeneity Religious and cultural rural communities. The ways and methods used by alumni in shaping the homogeneity of the religious and cultural character of rural communities is to teach, preach and exemplify religious teachings /values on the rural community
\end{abstract}

\begin{abstract}
Abstrak
Madrasah sebagai lembaga pendidikan Islam tertua setelah pondok pesantren telah diakui memiliki kontribusi yang sangat besar terhadap perilaku keberagamaan masyarakat Islam di Indonesia. Madrasah Al-
\end{abstract}


Jauharotunnaqiyyah Cibeber merupakan salah satu madrasah yang telah berdiri sejak tahun 1924, yang berkontribusi dalam melahirkan alumnialumni yang berkompeten dalam bidang agama yang tersebar di wilayah Banten dan sekitarnya. Pada penelitian ini penulis mencari tahu, apakah ada peranan alumni madrasah Al-Jauharotunnaqiyyah cibeber dalam membentuk karakter homogenitas keberagamaan dan budaya masyarakat pedesaan di wilayah kecamatan cebeber kota cilegon tersebut. Berdasarkan hasil penelitian yang telah dilakukan di masyarakat pedesaan Kecamatan Cibeber Kota Cilegon yang terdiri dari 6 desa, yaitu:Desa Cibeber, Kedaleman, Karangasem, Kalitimbang, Bulakan dan Desa Cikerai, dapat disimpulkan bahwa, alumni madrasah Al-Jauharotunnaqiyyah Cibeber sangat berperan dalam membentuk homogenitas keberagamaan dan budaya masyarakat pedesaan tersebut. Cara dan metode yang digunakan alumni dalam membentuk homogenitas karakter keagamaan dan budaya masyarakat pedesaan adalah mengajarkan, mendakwahkan, dan mencontohkan ajaran/ nilai-nilai agama terhadap masyarakat pedesaan tersebut.

Kata Kunci: Madrasah, Homogenitas dan Karakter Keagamaan.

\section{A. Pendahuluan}

Madrasah dianggap sebagai lembaga yang secara khusus mentransmisikan ilmu-ilmu agama dengan memberikan penekanan khusus pada bidang fiqih, tafsir, dan hadits dan tidak memasukkan ilmu-ilmu umum dalam kurikulumnya. Hal ini menurut Azzumardi Azra disebabkan karena tiga alasan: pertama, ini berkaitan dengan pandangan tentang ketinggian ilmu-ilmu keagamaan yang dianggap mempunyai supremasi lebih dan merupakan jalan cepat menuju Tuhan. Kedua, secara institusional madrasah memang dikuasai oleh mereka yang ahli dalam bidang agama. Dan ketiga, berkenaan dengan kenyataan bahwa hampir seluruh madrasah didirikan dan dipertahankan dengan dana wakaf dan penguasa politik Muslim atau dermawan kaya, karena didorong oleh adanya motivasi kesalehan.

Dengan kurikulum yang terfokus pada bidang keagamaan tersebut, madrasah justru dapat diterima luas di kalangan masyarakat, karena materi 
pokok yang diajarkan madrasah pada saat itu seperti fiqih, dianggap memenuhi kebutuhan masyarakat dan dapat diberikan pada anggota masyarakat dalam segala tingkatan umur. Di samping itu, para pengajar madrasah adalah para ulama yang notabene merupakan panutan masyarakat serta pembela kepentingan mereka dan memiliki kedudukan khusus dalam pemerintahan. ${ }^{1}$ Madrasah Cibeber Cilegon dalam format belajar mengajarnya sesungguhnya adalah pesantren yang berbentuk kelas, sehingga dalam proses transformasi ilmu, nilai-nilai keagamaan dan juga dalam pembentukan karakter siswa, sama persis dengan pesantren. Sehingga output lulusan Madrasah Cibeber memiliki kualitas keilmuan dan karakter sama dengan output dari pesantren.

Output lulusan Madrasah Cibeber meskipun setingkat lulusan Sekolah Lanjutan Tingkat Atas (SLTA), akan tetapi peran serta mereka dalam membentuk homogenitas karakter keagamaan dan tradisi kegamaan masyarakat pedesaan di Cilegon sangat signifikan.

\section{B. Karakteristik Masyarakat Pedesaan}

Menurut kamus lengkap Bahasa Indonesia, karakter merupakan sifat-sifat kejiwaan, akhlak atau budi pekerti yang membedakan seseorang dari yang lain, tabiat, watak.Berkarakter artinya mempunyai watak, mempunyai kepribadian. ${ }^{2}$ Menurut bahasa, karakter adalah tabiat atau kebiasaan. Sedangkan menurut ahli psikologi, karakter adalah sebuah sistem keyakinan dan kebiasaan yang mengarahkan tindakan seorang individu. Karena itu, jika pengetahuan mengenai karakter seseorang itu dapat diketahui, maka dapat diketahui pula bagaimana individu tersebut akan bersikap untuk kondisikondisi tertentu. ${ }^{3}$

1 Abuddin Nata, Sejarah Pendidikan Islam Pada Periode Klasik Dan Pertengahan, (Jakarta: PT. Raja Grafindo Persada, 2004), h. 178.

2 Kamisa, Kamus Lengkap Bahasa Indonesia, (Surabaya: Kartika, 1997), h. 281.

3 N.K. Singh and A.R. Agwan, Encyclopaedia of the Holy Qur'an, Edisi I (New Delhi: Balaji Offset, 2000), h. 175. 
Istilah karakter juga dianggap sama dengan kepribadian atau ciri atau karakteristik atau gaya atau sifat khas dari diri seorang. ${ }^{4}$

Masyarakat dan pedesaan atau desa, dua kata yang mempunya arti tersendiri. Untuk mendapatkan pengertian dari dua kata ini harus diartikan terlebih dahulu kata perkata. Misalnya, Masyarakat diartikan golongan besar atau kecil yang terdiri dari beberapa manusia dengan atau karena sendirinya bertalian secara golongan dan pengaruh-mempengaruhi satu sama lain. ${ }^{5}$ Paul H. Landis seorang sarjana sosiologi perdesaan dari Amerika Serikat, mengemukakan definisi tentang desa dengan cara membuat tiga pemilahan berdasarkan pada tujuan analisis. Untuk tujuan analisis statistik, desa didefinisikan sebagai suatu lingkungan yang penduduknya kurang dari 2500 orang. Untuk tujuan analisa sosial psikologi, desa didefinisikan sebagai suatu lingkungan yang penduduknya memiliki hubungan yang akrab dan serba informal di antara sesama warganya. Sedangkan untuk tujuan analisa ekonomi, desa di definisikan sebagai suatu lingkungan yang penduduknya tergantung kepada pertanian. ${ }^{6}$

Pandangan tentang kedua kata diatas yaitu masyarakat pedesaan atau desa dapat diartikan sebagai masyarakat yang memiliki hubungan yang lebih mendalam dan erat dan sistem kehidupan umumnya berkelompok dengan dasar kekeluargaan. Sebagian besar warga masyarakat hidup dari pertanian. Masyarakat tersebut homogen, seperti dalam hal mata pencaharian, agama, adat-istiadat dan sebagainya.

Masyarakat desa selalu memiliki ciri-ciri atau dalam hidup bermasyarakat, biasanya tanpak dalam perilaku keseharian mereka. Pada situasi dan kondisi tertentu, sebagian karakteristik dapat digeneralisasikan pada kehidupan masyarakat desa di daerah tertentu. Masyarakat desa juga ditandai dengan

4 Sjarkawi, Pembentukan Kepribadian Anak; Peran Moral, Intellektual, Emosional, Dan Sosial Sebagai Wujud Membangun Jatidiri, (Jakarta: PT. Bumi Aksara, 2006), h. 11.

5 Hassan Shadily, Sosiologi Untuk Masyarakat Indonesia, (Jakarta: Rineka Cipta, 1993), h. 47.

${ }^{6}$ Rahardjo, Pengantar Sosiologi Pedesaan Dan Pertanian, (Yogyakarta: Gadjah Mada University Press, 1999), h. 30. 
pemilikan ikatan perasaan batin yang kuat sesama warga desa, yaitu perasaan setiap warga/anggota masyarakat yang amat kuat dan pada hakekatnya bahwa seseorang merasa merupakan bagian yang tidak dapat dipisahkan dari masyarakat itu sendiri dimanapun ia hidup dicintainya serta mempunyai perasaan bersedia untuk berkorban setiap waktu demi masyarakatnya atau anggota-anggota masyarakat, karena beranggapan sama-sama sebagai masyarakat yang saling mencintai saling menghormati, mempunyai hak tanggung jawab yang sama terhadap keselamatan dan kebahagiaan bersama di dalam masyarakat.

Yang menjadi ciri masyarakat pedesaan antara lain; pertama, di dalam masyarakat pedesaan di antara warganya mempunyai hubungan yang lebih mendalam dan erat bila dibandingkan dengan masyarakat pedesaan lainnya di luar batas wilayahnya. Kedua, sistem kehidupan umumnya berkelompok dengan dasar kekeluargaan. Ketiga, sebagian besar warga masyarakat pedesaan hidup dari pertanian. Keempat, masyarakat tersebut homogen, seperti dalam hal mata pencaharian, agama, adat istiadat, dan sebagainya.

\section{Kehidupan Keagamaan Masyarakat Pedesaan Kota Cilegon}

Kehidupan sosial budaya dan keagamaan masyarakat Cilegon tidak terlepas dari pengaruh budaya Kesultanan Banten, sebagai salah satu pusat penyebaran Islam di Nusantara pada masa lampau dan juga perjuangan rakyat Cilegon pada masa lalu, yaitu peristiwa Geger Cilegon 1888. Kondisi demikian telah menempa masyarakat Cilegon untuk semakin mendalami dan mengembangkan nilai-nilai agama, dimana madrasah dan pesantren tumbuh dan berkembang demikian juga ulama dan cendekiawan muslim telah banyak lahir.

Di Cilegon sendiri telah berdiri dua lembaga madrasah dan pesantren besar yang berkembang pada saat itu hingga kini yaitu perguruan Islam AlKhairyah Citangkil dan Madrasah Jauharatunnaqiyah Cibeber. Masyarakat Cilegon dahulu umumnya banyak menimba ilmu di kedua madrasah atau 
pesantren tersebut maupun di pesantren-pesantren lainnya di pulau Jawa. Dengan latar belakang yang demikian telah memberikan warna pada masyarakat Cilegon sebagai masyarakat yang berpegang teguh dan taat dalam menjalankan agama. ${ }^{7}$

\section{Karekter Keagamaan dan Tradisi Keagamaan}

Setidaknya penghayatan keagamaan masyarakat dapat diukur dengan beberapa indikator, yaitu meliputi beberapa dimensi; Pertama, dimensi keyakinan. Dimensi ini berkaitan dengan seperangkat kepercayan dan keyakinan seseorang terhadap suatu ajaran agama yang bersumber dari realitas yang mutlak. Di dalam Islam misalnya, terdapat penekanan yang demikian kuat agar setiap muslim mempunyai aqidah (sistem kepercayaan dan keimanan) yang kokoh yang tidak mudah dipengaruhi oleh aqidah yang lainnya.

Selanjutnya, Kedua, dimensi praktek agama. Dimensi ini berkaitan dengan ketaatan seseorang pemeluk agama dalam mengajarkan agamanya terutama yang berbentuk ritual, seperti shalat, puasa, zakat, haji dalam Islam. Ketiga, dimensi pengalaman. Pengalaman agama merupakan tanggapan pemeluk agama yang melibatkan akal, perasaan dan kehendak hati terhadap apa yang dihayati sebagai realitas mutlak. Keempat, dimensi pengetahuan atau intelektual. Pada demensi ini mengacu padaharapan bahwa orangorang yang beragama paling tidak memiliki sejumlah pengetahuantentang dasar-dasar keyainan dan juga ritus-ritus, kitab suci dan tradisi-tradisi. Kelima, dimensi konsekwensi, yaitu keberagamaan diukur pada akibat yang ditimbulkan dalam kehidupan sosial. Agama diharapkan memberikan pengaruh secara nyata dalam kehidupan sosial manusia. ${ }^{8}$

7 Umdatul Hasanah, "Pondok Tradisional Dan Industrilaisasi (Eksisensi Dan Peran Pondok Pesantren Tradisional Dalam Pembangunan Masyarakat Kota Industri Cilegon,"” Laporan Penelitian (Cilegon, 2008).

8 R. Stark dan C.Y. Lock dalam Roland Robertson, Agama Dalam Analisa Dan Interpretasi Sosiologi, 1988. 


\section{Sekilas Sejarah Singkat Madrasah Al-Jauharotunnaqiyyah Cibeber}

Madrasah ini didirikan oleh KH. Abdul Lathif bin Ali Jaya pada tahun 1924 (versi lain 1926), beliau mendirikan madrasah setelah mendapatkan dukungan dari masyarakat Cibeber dan rekan-rekannya terutama $\mathrm{KH}$. Suchari. Sebelum menjadi madrasah Al-Jauharotunnaqiyyah madrasah ini semula bernama Tarbiyatul Athfal yang terletak di perkampungan Cibeber, setelah mendapatkan wakaf tanah dari mertuanya, yakni haji Anhar, yang terletak di sebrang jalan perkampungan Cibeber tepatnya kampung Cipucang Cibeber pada tahun 1931, maka madrasah dipindah ke tempat tersebut dan berganti nama menjadi perguruan Islam AlJauharotunnaqiyyah.

Sosok KH. Abdul Lathif bin Ali sendiri adalah sosok ulama kharismatik dan diakui sebagai mursyid dari tariqat Qadariyah dan Naqsabandiyah Cibeber yang aktif melaksanakan pembinaan keagamaan/pengajianpengajian melalui majlis-majlis ta'lim sejak tahun 1918 M. Setelah beliau wafat, penanggung jawab madrasah dilanjutkan oleh anak dan cucucucunya yaitu, KH. Ahmad Najiullah Lathifi (1960 s-d 1999), KH. Tb. Fuad Syihabuddin (1999 s-d 2007), dan KH. Abd Rasyid 2007-sampai dengan sekarang. ${ }^{9}$ Sampai dengan saat ini madrasah Al-Jauharotunnaqiyyah telah memiliki 114 cabang yang tersebar di beberapa daerah seperti: Kota Cilegon, Kota dan Kab. Serang, Kota dan Kab. Tangerang, Jakarta, Kota Bandar Lampung, Kab. Lampung Selatan dan sebagian wilayah Jawa Barat. ${ }^{10}$

Sistem pengajaran di madrasah Al-Jauharotunnaqiyyah tidak jauh berbeda dengan apa yang berlaku di pesantren, yaitu menggunakan metode tradisional seperti sorogan, bandungan maupun wetonan. Karena sesungguhnya madrasah Al-Jauharotunnaqiyyah adalah pesantren yang berbentuk sekolah atau sistem klasikal.

9 Yunus Gozali, Dalam Lintasan Sejarah KH. Abdul Lathif Bin KH. Ali, (Cibeber, 2008), h. 4.

${ }^{10}$ Selayang Pandang Pesantren Al-Djauharotunnaqiyyah, Data diambil di Pusat Informasi Pesantren (PIP) Al-Jauharotunnaqiyyah. 
Sementara itu, berkaitan dengan alumni madrasah A1Jauharotunnaqiyyah sebagian besar berprofesi menjadi ustadz di madrasah, guru ngaji di desa, kyai pesantren, kyai ilmu hikmah, ulama', dosen, organisatoris dan juga sebagian berprofesi sebagai masyarakat biasa akan tetapi di masyarakat akan tetap di anggap sebagai orang yang berilmu (di orangkan).

\section{Homogenitas Karakter Keagamaan Masyarakat: Sebuah Kontribusi} Alumni Madrasah Al-Jauharotunnaqiyyah Cibeber

Setelah dilakukan penelitian terhadap masyarakat di beberapa pedesaan yang terletak di wilayah Kecamatan Cibeber Kota Cilegon, peneliti menemukan fenomena bahwa karakter keagamaan masyarakat pedesaan tersebut bersifat homogen. Dan terjadinya homogenitas tersebut disebabkan adanya peran para alumni madrasah Al-Jauharotunnaqiyyah Cibeber yang berprofesi sebagai ustadz, guru ngaji, kyai, ulama, dan pimpinan organisasi desa. Mereka para alumni senantiasa aktif mentransformasi doktrin-doktrin ajaran dari madrasah Al-Jauharotunnaqiyyah dengan cara mengajarkan, mencontohkan dan mendakwahkan nilai-nilai ajaran agama kepada masyarakat baik melalui majlis-majlis ta'lim, pengajian di rumah-rumah, kegiatan kerohanian pemuda Islam (Rohis) serta melalui lembaga pendidikan madrasah diniyah awaliyah yang berdiri atas inisiatif dari para alumni.

Berikut ini adalah bentuk-bentuk homogenitas karakter keagamaan masyarakat pedesaan di Kecamatan Cibeber Kota Cilegon.

1) Aqidah Ahlu Sunnah wal Jama'ah, keyakinan akan kebenaran ajaran Islam yang senantiasa dipegang erat-erat oleh masyarakat pedesaan di wilayah kecamatan Cibeber adalah aqidah ahlu sunnah wal jama'ah yang didirikan oleh Abu Hasan Al-Asy'ari dan Abu Mansur AlMaturidi.

2) Fiqh ibadahnya mengikuti madzhab Imam Syafii, masyarakat pedesaan di wilayah kecamatan Cibeber dalam menjalankan seluruh 
ibadah mahdhoh maupun ghairu mahdhohnya selalu dari yang beraliran madzhab Syafii. Bahkan kitab-kitab yang diajarkan para alumni madrasah cibeber mayoritas adalah kitab dari karangan Imam Syafii dan murid-muridnya atau pengikutnya. Dalam hal ini, masyarakat pedesaan di wilayah kecamatan Cibeber merasa tabu atau asing ketika melihat ada salah seorang warga dari luar desa tersebut atau tamu yang mempraktekkan ibadahnya tidak seperti yang selama ini mereka fahami, bahkan besar kemungkinan bagi warga yang menjalankan ibadah yang berbeda tersebut akan dipandang sebelah mata dan bahkan bisa dianggap sesat.

3) Akhlaq atau tasawufnya adalah mengikuti ajaran Imam al-Ghozali dan Ibn Atha'illah Al-Iskandari, hal ini terlihat dari intensitas para alumni belajar dan mengajarkan kepada masyarakat pedesaan di wilayah kecamatan Cibeber kitab-kitab karya Imam Al-Ghozali seperti kitab Ihya' Ulumuddin dan kitab Al-Hikam karya Ibn Atha'illah AlIskandari.

4) Tarekat Qadiriyah dan Naqsabandi adalah tarekat yang dijadikan sebagai pegangan dalam melakukan wirid, berdzikir dll. Bahkan pada setiap kali hendak melakukan tahlilan/sejenisnya, maka bacaanbacaan yang dibaca akan sama, serta nama-nama tokoh tarekat di atas akan selalu disebut dalam hadharotnya.

5) Ormas yang diikuti adalah NU, meskipun secara administratif mereka tidak terdaftar sebagai anggota NU, tetapi setiap kali ada kegiatan ke NU-an mereka akan turut serta. Sehingga sering kali mereka disebut sebagai warga NU kultural bukan struktural.

\section{E. Homogenitas tradisi keagamaan masyarakat pedesaan kota Cilegon}

Sementara itu terkait dengan homogenitas karakter sosial dan budaya yang senantiasa diajarkan dan dipertahankan ajaran-ajarannya oleh para alumni madrasah Al-Jauharotunnaqiyyah di desa-desa tersebut adalah terkait dengan beberapa budaya beikut ini: 
1) Muludan (maulid), yaitu merayakan hari lahir Nabi Muhammad SAW 12 Rabi'ul Awal, dalam perakteknya perayaan ini bisa dilaksanakan mulai tanggal 1 s-d 29 Rabi'ul Awal dengan kemasan acara membaca kitab berjanzi/maulid dhiba'i, bacaan kitab tersebut dilombakan kemerduan, kekompakan dan inovasi/kreatifitas nada-nada syair/ lagunya. Sementara peserta lomba terdiri dari warga/masyarakat 2 desa yang berbeda-beda. Dan bagi masyarakat yang bertindak sebagai tuan rumah, menyiapkan panjang atau segala macam bentuk hiasan baik berbentuk kendaraan, binatang atau rumah ibadah yang berisikan makanan pokok, kain pakain, perabot rumah tangga, furnitur, hewan ternak, dan tentu saja dihiasi dengan uang-uang yang ditempelkan atau digantungkan pada hiasan tersebut dengan nilai jutaan rupiah. Panjang-panjang ini akan diberikan kepada peserta lomba dzikir baik kepada yang menang maupun yang kalah dengan diarak (diiringi) oleh tuan rumah menggunakan kendaraan bermotor dan juga drum band.

2) Rajaban (istihfalan), yaitu merayakan peristiwa Isro Mi'roj yang di adakan pada setiap bulan Rajab. Dalam perakteknya bisa dilaksanakan dari mulai tanggal 1-29 Rajab atau lebih, tidak harus pada tanggal 27 Rajab saja.Perayaan ini bisa beragam macam jenisnya, akan tetapiyang umum dilaksanakan adalah pembacaan kisah perjalanan Isro Mi'roj nabi Muhammad SAW oleh santri/siswa dari madrasah yang terdapat di desa tersebut dengan mengundang seluruh warga masyarakat, tokoh-tokoh agama masyarakat sekitar dan yang pasti mengundang pengurus besar Yayasan Madrasah Al-Jauharotunnaqiyyah Cibeber Pusat. Bagi santri/siswa yang maju di atas podium dan membacakan kisah Isro Mi'roj dengan hafalannya akan di sawer (dilempari/ dikalungi uang) oleh orang tua, dan sanak saudara dari santri/siswa tersebut.

3) Rowahan, membuat makanan pokok yang akan dibagikan ke saudarasaudara yang berada di desa sebelah. Dan di bulan ini pula diadakan 
acara malam nishfu sya'ban dengan membaca QS. Yasin di Masjid setelah shalat Maghrib pada malam ke 16 bulan sya'ban.

4) Qunutan, yaitu membuat ketupat atau lepet pada saat bulan puasa Ramadhan sebagai tanda telah memasuki hari puasa yang ke 16 dan pada saat rakaat terakhir setelah ruku' dalam shalat witir membaca do'a qunut.

5) Rebowekasan (tolak bala'), yaitu membaca Manaqib Syekh Abdul Qadir Jaelani yang dilakukan oleh ustadz atau kyai di tempat pojok-pojok desa dengan dihadiri warga sambil membawa/ menyediakan pisang, sirih, beras, sebotol atau satu teko air matang dengan tujuan ngalap berkah dan terhindar dari bala', warga juga dianjurkan membuat selimpu (makanan sejenis beras, dibungkus dengan daun pisang) dan dibawa ke masjid yang akan dibagikan ke warga setelah shalat talak bala?

6) Berkaitan dengan jenazah: melayat (ta'ziyah) dengan memberi satu piring/baskom beras kepada sohibul musibah, ngajeni (membaca) QS. Yasin atau QS. Al-Mulk sebelum jenazah dimandikan, sambutan dari perwakilan keluarga jenazah terkait permohonan maaf dan hutang piutang, memberikan amplop berisi uang kepada yang ikut menyolati jenazah, mentalqin dan mengadzani jenazah ketika menguburkan, memberi makan kepada yang mengurusi jenazah sepulang dari kuburan, membaca al-qur'an baik di rumah sohibul musibah maupun di kuburan selama 7-40 hari dan tahlilan selama 7 hari, serta hari-hari ke 15, 25, 40 dan 100.

7) Selametan dengan cara saweran (melempar uang receh dicampur beras kuning kepada anak-anak tetangga) sebagai wujud ungkapan rasa syukur karena telah sembuh dari sakit, bayi baru bisa berjalan, menyambut iringan dari rombongan pengantin, dan setelah bisa membeli kendaraan bermotor baru.

8) Marhabanan setiap malam jum'at atau setiap kali adanya pemberian nama dan menyukur rambut bayi dengan menggendong bayi 
memutari undangan yang hadir/datang dalam acara marhabanan tersebut.

9) Churafat, melempar garam ke atap rumah, memasang sapu lidi terbalik, membuat sate dari bawang, tomat dan cabe yang diletakkan di (tungku) tempat masak nasi dan lauk pauk ketika sedang ada hajatan nikah atau lainnya dengan harapan terhindar dari hujan atau apa saja yang dianggap akan mengganggu acara hajatan tersebut.

10) Wawacan syekh atau maca Syekh Abdul Qadir Jaelani adalah acara yang sering dilakukan oleh masyarakat pedesaan di wilayah kecamatan Cibeber ketika acara khitanan, kawinan, naik haji, membangun dan ruwatan rumah, membuka warung/toko baru atau membeli kendaraan baru.

11) Baca Kitab Dalailul Khoirot setiap sore menjelang buka puasa bulan ramadhan di masjid-masjid atau mushola.

\section{F. Kesimpulan}

Berdasarkan hasil penelitian yang peneliti lakukan terhadap masyarakat pedesaan di wilayah kecamatan cibeber kota cilegon yang terdiri dari 6 desa, yaitu: Desa Cibeber, Kedaleman, Karangasem, Kalitimbang, Bulakan dan Desa Cikerai, maka dapat disimpulkan bahwa alumni madrasah AlJauharotunnaqiyyah Cibeber sangat berperan dalam membentuk homogenitas keberagamaan dan budaya masyarakat pedesaan tersebut. Adapun cara dan metode para alumni dalam membentuk homogenitas karakter keagamaan dan budaya masyarakat pedesaan tersebut yaitu dengan cara mengajarkan, mendakwahkan, dan mencontohkan ajaran/nilai-nilai agama terhadap masyarakat pedesaan tersebut. Adapun sarana atau media yang digunakan adalah, majlis ta'lim, mendirikan madrasah diniyah, mengaji ba'da maghrib di rumah-rumah alumni, dan juga dengan cara mengadakan acara-acara peringatan pada hari-hari besar Islam. 
Homogenitas yang telah dibentuk oleh para alumni madrasah aljauharotunnaqiyyah cibeber tersebut adalah terakait karakter keagamaan yang meliputi tentang akidah, ibadah, akhlak dan muamalah. Sementara terkait dengan karakter tradisi keagamaan adalah tentang: muludan, rajaban, rowahan, qunutan, rebu wekasan, saweran, marhabanan, wewacan syaikh (Manaqib Abdul Qadir Jailani), membaca Kitab dala'ilul Khairot menunggu ta'jil puasa Ramadhan dan hal-hal yang berkaitan dengan tata cara mengurus jenazah/ mayit.

\section{Daftar Pustaka}

Gozali, Yunus. Dalam Lintasan Sejarah KH. Abdul Lathif Bin KH. Ali,. Cibeber, 2008.

Hasanah, Umdatul. “Pondok Tradisional Dan Industrilaisasi (Eksisensi Dan Peran Pondok Pesantren Tradisional Dalam Pembangunan Masyarakat Kota Industri Cilegon."” Laporan Penelitian. Cilegon, 2008.

Kamisa. Kamus Lengkap Bahasa Indonesia,. Surabaya: Kartika, 1997.

Nata, Abuddin. Sejarah Pendidikan Islam Pada Periode Klasik Dan Pertengahan,. Jakarta: PT. Raja Grafindo Persada, 2004.

Rahardjo. Pengantar Sosiologi Pedesaan Dan Pertanian,. Yogyakarta: Gadjah Mada University Press, 1999.

Robertson, Roland. Agama Dalam Analisa Dan Interpretasi Sosiologi, 1988.

Shadily, Hassan. Sosiologi Untuk Masyarakat Indonesia,. Jakarta: Rineka Cipta, 1993.

Singh, N.K., and A.R. Agwan. Encyclopaedia of the Holy Qur'an,. Edisi I. New Delhi: Balaji Offset, 2000.

Sjarkawi. Pembentukan Kepribadian Anak; Peran Moral, Intellektual, Emosional, Dan Sosial Sebagai Wujud Membangun Jatidiri,. Jakarta: PT. Bumi Aksara, 2006. 